\title{
Teaching Pastoral Theology as a Pedagogically Oriented Discipline in the Educational Institutions of the Orthodox Church in Ukraine (Beginning of the 19th - End of the 60's of the 19th Century)
}

\author{
Tetiana Tverdokhlib \\ H. S. Skovoroda Kharkiv National Pedagogical University, Alchevskykh Street, 29, Kharkiv, \\ Ukraine \\ tst.khnpu@gmail.com
}

\begin{abstract}
Keywords: Pastoral Theology, theological seminary, theological academy, the Orthodox Church, Ukraine.
\end{abstract}

\begin{abstract}
The article focuses on the pedagogical component in the content of Pastoral Theology in the Ukrainian educational institutions of the Orthodox Church, which were included in the system of religious education of the Russian Empire at the beginning of the nineteenth century - at the end of the 1860's. Basing on the studied works "On Positions of Parish Presbyters" by the bishop of the Smolensk Parfenii and the Archbishop of Mogilev, Georgii (Konyskyi), "Letters on Positions of Sacred Rank" by Olexandr Sturdza, "Pastoral Theology" by Archimandrite Anthonii (Amfiteatrov), as well as programs, lecture notes and lecture reviews of lecturers of theological seminaries and the Kiev Theological Academy it has been established that much attention at classes on Pastoral Theology was paid to the preparation of future priests for the religious and moral upbringing of parishioners. The main forms and methods of teaching Pastoral Theology have been presented on the basis of the analysis of archival materials, historical, pedagogical literature. Attention is drawn to the widespread dissemination in the seminaries of rote learning and text dictating, despite the prohibition of such methods by the 1814 Statute. The quality of teaching and staffing of this subject in the secondary and higher Ukrainian educational institutions of the Orthodox Church in the period under research. It has been proved that Pastoral Theology in seminaries was on an equal footing with other branches of theology: teachers understood its great importance for future presbyters and paid much attention to the subject as distinct from the Kiev Theological Academy.
\end{abstract}

\section{Introduction}

Recently, there has been an increase of interest in religion, Christian moral values in the society of countries with an atheistic past. It serves as a background for the transformation of value and sense orientation of the population. Problems of social, economic and political nature, lack of confidence in the future encourage contemporary people to return to the fold of the Church. The modern priest must carry out active educational work among the parishioners and promote their spiritual growth. The effectiveness of this activity to a large extent depends on the preparation of future pastors in religious educational institutions for the moral and religious upbringing of the flock. In order to improve this preparation, it is necessary to turn to the achievements of modern educators and use creatively the historical and pedagogical experience. In particular, it is necessary to take into account the miscalculations and achievements in organizing the study of Pastoral Theology in the educational institutions of the Orthodox Church in Ukraine at the beginning of the nineteenth century - at the end of the 60's of the nineteenth century.

During the period under research, most of the Ukrainian lands belonged to the Russian Empire, where Orthodoxy had the status of a state religion. With the assertion of absolutism in Russia, the Orthodox Church was actually in complete subordination to secular authority, which led churchmen with the help of the state apparatus. The tsarist government, while conducting domestic policy, had to rely on the Orthodox clergy that proved the religious foundation of the tsar power, justified the miscalculations of the government and praised its achievements. Besides this activity, religios and moral education of parishioners was the first duty of the representatives of the 
Orthodox Church. The Orthodox clergy quite successfully carried out religious education of people, had great influence on assimilation of Christian norms by adults and children and helped people in moments of spiritual doubts.

Taking into account the great importance of the educational work of the clergy with the flock in the period under research, theological seminaries and academies prepared for it. This was mainly done in Pastoral Theology lessons. In our view, Pastoral Theology taught at the educational institutions of the Orthodox Church of the Russian Empire cannot be accepted solely as a theological discipline, since it had a significant pedagogical component. In this article, we aim to reveal the contents of Pastoral Theology as a pedagogically oriented discipline in religious educational institutions, to characterize the main forms and methods of teaching this subject and peculiarities of its staffing.

\section{Materials and Methods}

There was used a complex of scientific research methods as follows: General scientific (analysis, comparison, systematization, etc.) to generalize the archive material and other sources; comparative-historical, which allowed comparing the features of teaching pastoral theology at Kiev Theological Academy and theological seminaries, to identify changes that occurred over the investigated period in the content of pastoral theology as a pedagogically-oriented discipline. In addition, a hermeneutical method played an important role in the study, which gave an opportunity to interpret texts of pastoral theology books, summaries and programs of theological disciplines and to discover the pedagogical component.

Reforming the Orthodox religious education on the Ukrainian lands of the Russian Empire. At the beginning of the nineteenth century the Russian Empire had a heavy burden of growing socio-economic and internal political problems. Alexander I (1801-1825) tried to manoeuvre between conservative and liberal measures, partially reorganizing various levels of state administration, with introducing economic, social, educational and other changes.

The reform of the education system of the Orthodox Church was carried out in the context of the liberal transformations of Alexander I. Its tasks were to centralize the management of the ecclesiastical school, to provide unity and continuity to educational institutions at all levels of the system, to unify curricula and textbooks. In addition, the reform had to raise the general level of educational institutions of the Orthodox Church, promote the development of theology in academies.

The analysis of the normative documents and historical literature has shown that "The Report on the Improvement of Religious Schools" proposed to the emperor on the 26th of June, 1808 was taken as a basis for the legislative acts on the reform of the ecclesiastical school [1-5].

This normative act and the orders issued on the same day determined the educational, administrative functions of the educational institutions of the Orthodox Church, as well as the sources of their material support. Like the four-level system of secular schools created in 18031804, four types of ecclesiastical educational institutions were introduced. They were parochial schools, district schools, seminaries and academies. In 1814, the statutes of theological seminaries and academies were officially approved $[6,7]$. They provided for the introduction of compulsory study of pastoral theology in these educational institutions.

There were Chernihiv, Podilla, Kyiv, Volyn, Katerinoslav, Poltava, Kharkiv and from 1838 Kherson theological seminaries functioning on the Ukrainian lands of the Russian Empire. Higher theological education was provided by the Kyiv Theological Academy (the KTA). The activities of the seminaries were regulated by the Statute of 1814 till 1867, and the activities of the academies were regulated by the Statute of 1814 until 1869.

The content of Pastoral Theology as a pedagogically oriented discipline. After the reorganization of the Ukrainian educational institutions of the Orthodox Church according to the statutes of 1814, Pastoral Theology as part of Theology was introduced to the course of the Kiev Theological Academy and theological seminaries. It had an important role in preparing future 
priests for the religious and moral upbringing of parishioners. The analysis of the works used in the KTA in the process of teaching this discipline in the early nineteenth century - at the end of the 60s of the nineteenth century allows us to characterize the content of pedagogical education received by academy students in the study of Pastoral Theology. The book "On Positions of Parish Presbyters" by the bishop of the Smolensk Parfenii and the Archbishop of Mogilev, Georgii (Konyskyi) ((1776) 2004) was the first textbook on the subject stated. The work was published in 1776, and by 1833 it had already had 21 reprints. Although the authors did not mention the scientific or educational nature of their work and intended it first and foremost for poorly educated pastors and those who "will crave for being a priest or just a clergyman"[8], it became the main textbook for teaching Pastoral Theology in higher theological educational institutions of the Russian Empire in the first half of the nineteenth century. The KTA was no exception. Since 1819, in the academy, this branch of theology was taught to "students by the classical book "On the Positions of the Parish Presbyters", which was widely represented in the funds of the library of the higher theological educational institution $[9,10]$.

The content of the "classical book" consists of four sections: 1) "introduction into position of a priest"; 2) "about the first part of the priest position, that is, about teaching parishioners"; 3) "on the second priest business, that is, about conducting the sacraments"; 4) "about prayer". The second section has a bright pedagogical orientation and prepares future pastors for the religious and moral upbringing of their own flock. It is divided into two parts, the first of which is devoted to the teaching in word, and the second deals with teaching in deed, "because the priest must teach his parishioners faith and good deeds: teach not only in word, but also in deed, that is, with the example of his life, so that his word was not dead and fruitless" [8].

Students of the Academy had to learn the main "types of teaching in word". There were only five of them and it was difficult to determine which criterion was the basis for the classification. So, the first type meant teaching the dogmas of religion to the entire flock in order to improve the person by faith, that is, it was intended for a religious and moral enlightenment. By implementing it, future pastors were recommended to take into account the individual characteristics of parishioners. For example, they were offered not to burden illiterate peasants with inexplicable theological terms, to teach them the most necessary and important things, "speaking with simple, clear and short words, and confirming with one or two proofs from the Word of God. And do not to depart from the interpretation of the member of the faith proposed until it is clearly understood by the audience" [8]. The teaching the dogmas of the religion of educated parishioners had to be organized in a completely different way, its content was expanded and complicated, other methods were used, homily in particular.

In our opinion, the other four "types of teaching in word" were set out by the authors of the textbook, depending on the particularities of the contingent that the presbyter should educate. Academy students got acquainted with the peculiarities of exerting educational influence on heretics, atheists (the second type); on "lawless", that is, people who violate moral norms (the third type); on the virtuous representatives of the flock (the fourth type); on "sad and despondent" (the fifth type) [8]. Despite certain shortcomings of the proposed classification, the separation of the "types" of teaching in word positively influenced the pedagogical training of students, since it trained them to implement a differentiated approach in educational work.

Considering "teaching in word", academy students studied such methods of education as: consolation, persuasion, revelation and punishment. At lessons of pastoral theology, students were led to the thought about the necessity of constant pedagogical diagnostics [8].

Mastering "teaching in deed" by future pastors, that is, understanding the great importance of the personal example of the priest was no less important along with "teaching in word". To this purpose , the work "On Positions of Parish Presbyters" covered the virtues that a priest must possess, namely: monogamy, chastity, that is, the ability to "curb any passion, especially corporal lusts", goodness, hospitality, truthfulness, wisdom, rationality, modesty, caution, fidelity, given in the work "On the Positions of the Parish Presbyters" [8]. Also, a presbyter was required to carry out 
"weariless vigil about the entrusted flock", to be not drinking, not quarrelling, calm, not envious, and not covetous, to manage his own house properly, to be engaged in the upbringing of his children, to have no pride [8].

The analysis of archival materials shows that, in addition to the work of Bishop of Smolensk Parfenii and the Archbishop of Mogilev, Georgii (Konyskyi), the work of Olexandr Sturdza "Letters on the Positions of the Sacred Rank" was used in educational process of the KTA [11]. Taking into consideration the epistolary form of information presentation, the lack of logic and systematicity in presentation, some contradictions and repetitions, it could not be taken as the main textbook. However, it could be successfully used to deepen and broaden students' knowledge of Pastoral Theology. Particularly, in the aspect of our research, the fifth of the seven books that the material of letters was divided into is important. It is the precisely the book where the problem of the religion teaching activity of a presbyter is covered, whereas there was not a word about it in the work "On the Positions of the Parish Presbyters". O. Sturdza reveals some peculiarities of the teaching the Law of God, defines certain rules by which a religion teacher should be guided in the process of teaching boys and girls. The author pays considerable attention not only to the mastering knowledge on the subject, but also to the need for religious and moral education of schoolchildren. In particular, according to O. Sturdza, the Orthodox upbringing of young Christian girls is necessary for them "to be able to comprehend their humble and at the same time high predestination in the graceful kingdom of Christ" [12]. The importance of involving students into independent work on the subject is also pointed out in the "Letters on the Positions of the Sacred Rank", because "... without reading of the auxiliary books alone, it is not possible to have real success in any science. Accordingly, religion teaching is not excluded from this rule as well" [12].

In 1854, the work of "Pastoral Theology", the author of which was the Rector of the KTA, Archimandrite Anthonii (Amfiteatrov), was published. It is based on the epistles of the Apostle Paul, the instructions and rules established by the oecumenical and local councils, the works of Gregory the Theologian, St. Zlatoust, Gregory of the Great and other Fathers of the Church; on his own pedagogical experience (he gave lectures on pastoral theology at the Kyiv Theological Seminary); on those groundwork of Pastoral Theology, which teachers of the St. Petersburg Theological Academy had (Father Anthonii brought educational notes on this subject from St. Petersburg). In some places, the textbook of Archimandrite Anthonii contains extracts from "On the positions of the parish presbyters". The work of "Pastoral Theology" was necessary for the ecclesiastical educational institutions, since it had to generalize and systematize the developments in this field of theology from 1776, that is, since the publication of the textbook of the bishop of Smolensk Parfenii and Archbishop of Mogilev Georgii (Konyskyi) [13].

Like the work "On the Positions of the Parish Presbyters", the textbook of the rector of the KTA had pedagogical orientation. It is stated in the textbook that "... the purpose of the pastoral service is ... enlightenment of people in faith and Christian piety, consecration with the grace of God, and guiding them to eternal salvation and bliss" [14]. From the duties of the priest, except "accomplishing the sacraments and divine service in genera", all others ("propagation of the word of God and teaching the people of Christian faith and piety", "guide to the salvation of the souls entrusted to him") are pedagogically oriented [14].

Taking into account the high purpose of pastoral activity and the need for positive educational effects, most of the source is devoted to the requirements to the pastor's personality, because his life and behaviour should be an example for parishioners. "The pastor is a teacher of faith and piety, and the light of Christ pours on people through him and enlightens them. He is the spiritual leader ... and, through his guidance, people achieve spiritual improvement and eternal salvation" [14]. As these requirements largely coincide with those proposed by the bishop of the Smolensk Parfenii and Archbishop Georgii of Mogilev (Konyskyi) and have been considered in a separate modern research [13], we will focus only on some of them. Only in the work "Pastoral Theology" it is determined that the pastor needs to have such virtues for conducting educational work in the parish as isight, communicability and elements of teaching skills. The latter are necessary for presbyters, so that at any time they can communicate with everyone with kindness, friendliness, compassion and Christian love, which should be expressed in tone of voice, facial expressions, gestures, etc. 
The rector developed the idea of the need for prudence and education of a presbyter. A pastor should have good cognitive abilities, developed memory, imagination, and speech. The educational activity of a priest implies his broad education, knowledge of rules and lectures, as well as the ability to impart his knowledge to others.

The section about "qualities of a pastor, shown in his relationship with other people" is presented in "Pastoral Theology" separately. It deals with the peculiarities of relationship between the priest and his own family, representatives of the authorities, members of the clergy, and others. Although it has been found out basing on the analysis of the source that the most important thing for a pastor is the relationship with his own flock, this is not mentioned in the stated section.

Father Anthonii paid very little attention to such an important function of a priest as the organization of primary education of children. It was defined as the second (after studying sciences) important domestic work [14].

As we can see, "Pastoral Theology" does not acquaint future presbyters with methods of religious and moral education of parishioners. This disadvantage, as well as others mentioned above, indicates incomplete work. The fact is that the publication of the second part of the textbook was planned, but it was never published.

If Pastoral Theology was taught mainly as one of the theological disciplines in the first half of the nineteenth century, it was often included into other subjects in the 1850's and 1860's. This led to narrowing of the content of Pastoral Theology. Thus, in 1861, there was no program on Pastoral Theology found among syllabuses. Basing on the study of "The Overview of the Lessons Taught to Students of the KTA of XX-th Year Specializing in the Class of Church Philology" by N. Favorov, it has been established that that year homiletics was supplemented with "Pedagogical Remarks on the Pastoral Guidance of the Shepherded". They acquainted with the essence and means of pastoral care of parishioners, the conditions for its success, the peculiarities of the educational work of a presbyter with different categories of people ("truly pious", those who have spiritual and moral problems, "apostates from the true faith") [15]. The study of "Notes of the Subjects Taught in the Academy in 1867-1868 and 1868-1869 academic years" also proves that the content of Pastoral Theology was limited to the topics indicated [16]. Of course, that situation did not contribute to expanding the knowledge of academy students that they received in the seminary on Pastoral Theology. However, it was the pedagogical component of the discipline that was singled out and students' knowledge of the religious and moral upbringing of the flock was deepened. Gradually, conditions were created for the replacement of Pastoral Theology with a new educational subject Pastoral Pedagogy.

In the secondary religious school, Pastoral Theology was also not taught as a separate subject, it was studied as part of Theology. Works of Bishop of Smolensk Parfenii and Archbishop of Mogilev Georgii (Konyskyi), Archimandrite Anthonii (Amfiteatrov) were also used in theological seminaries as teaching aids. The analysis of educational programs, lecture notes of the teachers of theology in the secondary religious educational institutions for different years of the first quarter of the nineteenth century allows us to assert that seminary students were offered to study some parts of the work "On the Positions of the Parish Presbyters". For example, in the Kyiv Theological Seminary and Podilla Theological Seminary, students had to learn general information about the priesthood, to examine in detail teaching in word (substantiation of its necessity, interpretation of its subject, sources, image) and pay attention to the basis of educational influence of the example of the presbyter on the life of the parishioners [17-20]. In the Katerinoslav Seminary, the content of Pastoral Theology was somewhat supplemented with themes about the importance of prayers and sacraments for the flock [21].

In 1840, the members of the Holy Synod, the leaders of the Kiev religious and educational district realized the importance of Pastoral Theology for graduates of seminaries: "since any priest, and even more so a village one ... needs the ability to have a beneficial effect on the morality of parishioners with irreproachability of life and the word of persuasion, but it is especially necessary to adapt Pastoral Theology to the duties of a rural priest ..." [22]. Archimandrite Iieremiia, the rector of the KTA, developed the syllabus on this branch of theology for seminaries of the religious and 
educational district that he headed. It was called "The Synopsis of the Doctrine on the Position of Parish Presbyters" [22]. In this syllabus, the themes were covered in more detail than in seminary programs and synopses of past years, the theme "Rules and warnings that should be kept in mind when preaching people of different age and different levels of education" appeared. The new document covered the essence and significance of the priesthood, dealt with the material on teaching in word (substantiation of its necessity, interpretation of its sources, peculiarities of educational work with different categories of the population) and briefly presented the significance of the educational influence of the example of the presbyter on life of parishioners. The syllabus also revealed the rules of conducting the sacraments and the importance of such a presbyter's duty as a prayer for people. The study of archival materials allows suggesting that secondary religious educational institutions did not always strictly adhere to the syllabus of the archimandrite Iieremiia [23-24]. For example, in the Kharkiv theological seminary the content of Pastoral Theology was restructured and the volume of some themes did not correspond to the volume proposed by the rector of the KTA.

Thus, despite some differences in seminary programs on Pastoral Theology, during the period under research the content of the discipline was based more on the propositions of the work "On the positions of the parish presbyters" by the bishop of the Smolensk Parfenii and Archbishop of Mogilev Georgii (Konyskyi). "Pastoral Theology" by Archimandrite Anthonii (Amfitheatrov) was rarely used in the educational process of Ukrainian religious seminaries, although, according to some scholars [25], it was intended precisely for them.

Forms and methods of teaching Pastoral Theology. Lectures and examinations should be regarded as main forms of teaching Pastoral Theology in the KTA. Due to them students had to learn the content of the subject. Also, the academy students could deepen their knowledge by writing the final work on this discipline, but they did not use such an opportunity. As an exception, the dissertation of the hieromonk Narkis (Sylvestrov) "The Teachings of the Holy Fathers about Pastoral Service in General in the Church of Christ" should be mentioned. Unfortunately, as a result of the analysis of the research, we can state that the pedagogical component of Pastoral Theology is practically not covered in the work [26].

The theoretical character and firmness of the postulates of theological sciences resulted in the wide spreading of rote learning and dictating texts in the seminaries, despite the prohibition of such methods by the Statute of 1814 . On the ground of historical and pedagogical literature studied, it has been found that the homework of students of secondary religious educational institutions consisted mainly of learning by heart notes as dictated and written during lessons or lectures (introduced from the 40's of the nineteenth century) [27-29]. In addition to dictations during lessons of Theology, there were conversations held when a student should literally reproduce the material learned. In the early 60 's of the nineteenth century, the correspondent of the ecclesiastical magazine noted that many mentors at that time understood the damage of rote learning for the development of students but anyway they required to learn home task word for word [28]. Archimandrite Ionikii after the revision of the Podilla, Poltava and Chernihiv seminaries in 1858 also pointed to rote learning as a significant disadvantage of the organization of educational matters in these educational institutions [30].

Theology examinations were always conducted orally. The analysis of archival sources gave us grounds to assert the importance and exceptional position of Theology examination [31-33]. It was here where high-ranking guests were always invited. So, on the $3^{\text {rd }}$ of July, 1844, from eight to twelve, "in the presence of His Eminence Filaret, Metropolitan of Kyiv, His Eminence Varlaam, Bishop of Chigirin, vicar of the Kyiv Metropolitanate, the Right Reverend Yosyf, members of the Academic and Seminary Board, all seminary students and students of the Academy, the students of the higher Department of the Seminary were examined on the class of Theological sciences" [33]. 
Features of staffing of teaching Pastoral Theology. More than twenty teachers, who taught Pastoral Theology, changed in the KTA during the first half of the nineteenth century. Mostly rectors of the academy and teachers who had a monastic rank had the honour and responsibility to teach Theological sciences (Table 1).

Table 1. Human Resources for the Teaching of Theological Disciplines at the Kiev Theological Academy in 1819-1869.

\begin{tabular}{|c|c|c|c|}
\hline № & $\begin{array}{l}\text { Name of Teacher (Monastic } \\
\text { Name) }\end{array}$ & $\begin{array}{l}\text { The Period of } \\
\text { Teaching Theological } \\
\text { Sciences at the KTA }\end{array}$ & $\begin{array}{l}\text { Position, Academic Title at the } \\
\text { Time of Teaching Theology at } \\
\text { the KTA }\end{array}$ \\
\hline 1 & $\begin{array}{l}\text { Matvii Mykhailovych } \\
\text { Bohdanov-Platonov-Antypov } \\
\text { (Moisei) }\end{array}$ & $1819-1823$ & $\begin{array}{l}\text { Rector, Bachelor, from } 1822- \\
\text { Doctor of Theology }\end{array}$ \\
\hline 2 & $\begin{array}{l}\text { Oleksandr Petrovych } \\
\text { Kryzhanovskyi (Smarahd) }\end{array}$ & $1821-1826,1828-1830$ & $\begin{array}{l}\text { Bachelor, from } 1824 \text { - Doctor of } \\
\text { Theology, 1828-1830 - Rector }\end{array}$ \\
\hline 3 & $\begin{array}{l}\text { Dionisii Oleksiiovych } \\
\text { Kunytskyi (Kyrylo) }\end{array}$ & $1826-1828$ & Rector, Professor \\
\hline 4 & $\begin{array}{l}\text { Yakiv Yevdokymovych } \\
\text { Mykhailov (Iustyn) }\end{array}$ & $1823-1828$ & Bachelor \\
\hline 6 & Mykhailo Pereverzin (Meliton) & $1829-1833$ & Bachelor \\
\hline 7 & $\begin{array}{l}\text { Ivan Oleksiiovych Borysov } \\
\text { (Inokentii) }\end{array}$ & $1830-1837$ & $\begin{array}{l}\text { Rector, Professor, Doctor of } \\
\text { Theology }\end{array}$ \\
\hline 8 & $\begin{array}{l}\text { Oleksii Andriiovych Shokotov } \\
\text { (Antonii) }\end{array}$ & $1834-1836$ & $\begin{array}{l}\text { Professor Extraordinary, } \\
\text { Academy Inspector }\end{array}$ \\
\hline 9 & $\begin{array}{l}\text { Klyment Ivanovych Muretov } \\
\text { (Dymytrii) }\end{array}$ & $1836-1851$ & $\begin{array}{l}\text { Bachelor, from } 1837 \text {-Professor, } \\
\text { 1838-1841 - Academy } \\
\text { Inspector, 1841-1851 - Rector }\end{array}$ \\
\hline 10 & $\begin{array}{l}\text { Oleksandr Mykolaiovych } \\
\text { Aretynskyi (Serafim) }\end{array}$ & $1837-1842$ & Bachelor \\
\hline 11 & $\begin{array}{l}\text { Pavlo Ivanovych Borysovych } \\
\text { (Afanasii) }\end{array}$ & $1838-1841$ & $\begin{array}{l}\text { 1838-1840- Bachelor, 1840- } \\
1841 \text { - Professor Extraordinary }\end{array}$ \\
\hline 14 & $\begin{array}{l}\text { Andrii Ivanovych Monastyrev } \\
\text { (Mykhailo) }\end{array}$ & $1842-1846$ & Bachelor \\
\hline 15 & $\begin{array}{l}\text { Andrii Ivanovych Kapustin } \\
\text { (Antonin) }\end{array}$ & $1846-1850$ & Bachelor \\
\hline 16 & $\begin{array}{l}\text { Dmytro Mykhailovych } \\
\text { Musatov (Daniil) }\end{array}$ & $1846(1847 ?)-1852$ & $\begin{array}{l}\text { Academy Inspector, Professor } \\
\text { Extraordinary }\end{array}$ \\
\hline 18 & $\begin{array}{l}\text { Yakov Havrylovych } \\
\text { Amfiteatrov (Antonii) }\end{array}$ & $1851-1858$ & $\begin{array}{l}\text { Rector, Professor, Doctor of } \\
\text { Theology }\end{array}$ \\
\hline 19 & Yakiv Ivanovych Lukin (Izrail) & $1858-1859$ & Rector, Doctor of Theology \\
\hline 20 & $\begin{array}{l}\text { Ivan Maksymovych Rudniev } \\
\text { (Ioannykii) }\end{array}$ & $1859-1860$ & Rector, Doctor of Theology \\
\hline 21 & Nazarii Antonovych Favorov & 1861 & Doctor of Theology \\
\hline 22 & $\begin{array}{l}\text { Mykhailo Prokopovych } \\
\text { Filaretov (Filaret) }\end{array}$ & $1860-1877$ & Rector, Doctor of Theology \\
\hline
\end{tabular}

Askochenskij, History of the Kiev Theological Academy. 
Since monks with higher theological education had far greater opportunities for career promotion than they could be offered by the Academy, the Holy Synod often moved them to higher positions. For example, Matvei Mikhailovich Bogdanov-Platonov-Antipov (Moisei), who was the rector of the academy during 1819-1823, Bachelor and Doctor of Theology (from 1822), became Staroruskii Bishop, vicar of Novgorod. And on the $23^{\text {rd }}$ of July, 1836, Professor of Theological Sciences, Inspector of the Academy Archimandrite Anthonii was appointed rector of the Poltava Seminary [34]. Moving of teachers, heavy load with administrative work often did not give teachers the opportunity to master effective teaching methods, to go deep into science, to learn to take into account the features of the student contingent of the KTA.

Belonging to the black clergy meant that a teacher was not a priest and had no opportunity to conduct educational work with parishioners. So, he mastered Pastoral Theology only on the theoretical level, he never had a pastoral practice, therefore he could not fully understand the specifics of this discipline. Considering that only a few of the Academy graduates became priests and most of them devoted themselves to teaching activities in educational institutions of the religious department of the Russian Empire, such teachers did not understand the need to study it by academy students. The tension between white and black clergy, as noted by I. Lomachinskaya [35] also did not favour the quality of teaching Pastoral Theology. Usually Dogmatic, Moral, Active and other Theologies were given first and thoroughly. Pastoral Theology was covered quickly at the end of the course in Theology.

No wonder that there is evidence of pedagogical skills of only some teachers of Pastoral Theology. So, it is known that Dymytrii (Muretov) did about his lectures. He "did not give to students and probably did not write them in full, but prepared for them so thoroughly, that usually for two hours running, without an abstract or even a piece of paper for reference, he spoke uninterruptedly, giving texts and extracts from the authors literally, with exact indication of volumes and pages of quoted works" [36].

There is also mention of scientific and pedagogical activities of the rector of the KTA Innokentii (Borisov), who introduced a new "method" of teaching Theology - historical and historical-comparative one. Preparing for classes, he mainly analyzed the original sources of the Orthodox doctrine, and also used textbooks of Western theological literature, mostly Protestant one. The teacher avoided using textbooks, which represented the old scholastic courses of theology. With the brilliant gift of presentation, the rector Innokentii revived the interest in academic studies of teachers and students at the theological academy [37].

The analysis of service records of the teaching staff of the Volyn, Katerinoslav, Kyiv, Podillya, Poltava, Kharkiv, Kherson and Chernihiv seminaries for different years of the period under research allows us to say that the situation in secondary educational institutions of the Orthodox Church was also complicated because of turnover of Theology teachers [38-44]. The archive materials studied let us state that these disciplines were taught by teachers with higher theological education, but most often they were rectors, seminary inspectors, who were often moved to other positions. It should be noted that, unlike the academy, Pastoral Theology was an important subject for seminary students, as most of them prepared for priest activities, so teachers paid considerable attention to it.

\section{Discussion}

Pastoral theology as an academic subject in retrospect represented in articles arm. Innokenty (Pustynsky), M. Makkaveysky, V. Pevnytsky, M. Glubokovsky, G. Florovsky, N. Sukhova. Brief digressions into the history of teaching pastoral theology in the Russian Empire represented in the textbooks and the lectures of Archimandrite John (Maslov), Bishop Benjamin (Milov), and others [45]. It reveals the content of pastoral theology as a theological discipline, it is generally lit institutional conditions of teaching the subject. The study expands understanding of the pastoral theology content, since it proves the existence of a pedagogical component. In addition, the paper first presents the information on the staffing of designated teaching educational discipline at the beginning of the nineteenth century - at the end of 60's of the nineteenth century, it is disclosed the application features the main forms and methods of training. 
Further research prospects are to study the content of training seminarians to the moral and religious education of the congregation in the second half of the nineteenth century - at the beginning of the twentieth century.

\section{Conclusions}

Thus, at the beginning of the nineteenth century, an important achievement in the development of the ecclesiastical school was the introduction of Pastoral Theology into curriculum at educational institutions of the Orthodox Church in Ukraine. It was this educational discipline that provided some pedagogical training of seminary and academy students. As a result of the analysis of the content of Pastoral Theology it was established that the pedagogical component included knowledge about the necessity of differentiated approach in the process of religious and moral education of parishioners, methods of education, the value of the personal example of a priest as a flock educator, the requirements for his personality, the need to teach the law of God and teach children in primary school and so on. This educational subject was not developed in the Kiev Theological Academy and in the 50's and 60's of the nineteenth century there was a significant narrowing of its contents: only pedagogical component was taught. Monk-teachers considered Pastoral Theology to be secondary subject as compared with other theological disciplines. The main forms of teaching were lectures and examinations. Unlike higher religious school, Pastoral Theology in the seminaries was equal to other branches of Theology; it was given considerable attention by teachers. The features of the development of this educational subject in the secondary religious educational institutions were turnover of teaching staff, orientation towards rote learning of information by seminary students. Lessons, lectures, homework, examinations, conversations, dictations have been found to be the basic methods and forms of teaching Pastoral Theology in seminaries.

\section{Conflict of Interest}

The author declares that there is no conflict of interest.

\section{References}

[1] Order, given to the Committee on the Improvement of Religious Schools. On Completion of Cases, entrusted to this Committee and on the Transfer to the Commission of Religious Schools of its Journals and All Information in its Consideration № 23. 124 from the 26th of June 1808, in Complete Collection of Laws of the Russian Empire: the First Collection: From 1649 to the 12th of December 1825, Vol. 30, Saint-Petersburg, Russian Empire, 1808 [Online]. Available: http://elib.shpl.ru/ru/nodes/208-t-30-1808-18091830\#page/397/mode/inspect/zoom/4

[2] Outline of Rules for Ecclesiastical Schools Creation and Clergy Upkeep at Churches № 23. 122 from the 26th of June, 1808, in Complete Collection of Laws of the Russian Empire: the First Collection: From 1649 to the 12th of December 1825, Vol. 30, Saint-Petersburg, Russian Empire, 1808 [Online]. Available: http://elib.shpl.ru/ru/nodes/208-t-30-1808-18091830\#page $/ 385 /$ mode $/$ inspect $/$ zoom $/ 4$

[3] V.A. Fedorov, Ecclesiastical Education in the Russian Orthodox Church in the XIX century, Pedagogy. 5 (2000) 75-83.

[4] V.M. Popovych, Development of System of Orthodox Theological Education in Ukraine: a Retrospective Analysis, Verges. 5 (2014) 6-11 [Online]. Available: http://nbuv.gov.ua/UJRN/Grani_2014_5_3 
[5] D. Kuklyarskij, Intellectual Education of the Clergy in the X1X century, Poltava eparchial registers. Informal department. 3 (1886) 84-101 [Online]. Available: https://vivaldi.nlr.ru/ap000021417/view\#page=8

[6] Approved by Emperor Project of the Statute of Theological Seminaries, in Complete Collection of Laws of the Russian Empire, Vol. 32, Saint-Petersburg, Russian Empire, 1830 [Online]. Available: http://elib.shpl.ru/ru/nodes/210-t-32-1812-18151830\#page/957/mode/inspect/zoom/4

[7] Approved by Emperor Project of the Statute of Theological Academies, in Complete Collection of Laws of the Russian Empire, Vol. 32, Saint-Petersburg, Russian Empire, 1830 [Online]. Available: http://elib.shpl.ru/ru/nodes/210-t-32-1812-18151830\#page/912/mode/inspect/zoom/4

[8] On the positions of the parish presbyters, Sretenskiy monastery, Moscow, Russia, 1776 repr. 2004 [Online]. Available: http://tvereparhia.ru/biblioteka-2/o/505-o-dolzhnostyakhpresviterov-prikhodskikh/9211-o-dolzhnostyakh-presviterov-prikhodskikh-1776-2004

[9] V.I. Askochenskij, History of the Kiev Theological Academy on the transformation of it in 1819, Jeduarda Vejmara printing house, Saint-Petersburg, Russian Empire,1863 [Online]. Available: http://books.e-heritage.ru/book/10086729

[10] Institute of Manuscripts of the V. I. Vernadskyi National Library of Ukraine, Kyiv. Fund 160, file 626 - Catalog of the KTA Library, 1826.

[11] Institute of Manuscripts of the V. I. Vernadskyi National Library of Ukraine, Kyiv. Fund 160, file 1328 - Extracts from minute-books of the KTA Board for 1845-1852.

[12] Aleksandr Sturdza, Letters on the Positions of the Sacred Rank, vol. 2, Odessa municipal printing house, Odessa, Russian Empire, 1841.

[13] T.S. Tverdokhlib, Researching the Work of Archimandrite Anthonii (Amfiteatrov) "Pastoral Theology" as a Historical and Pedagogical Source, in XIII International scientific and practical Conference "Methodology of modern scientific research"-2016, Kharkiv, Ukraine, 2016, pp. 139-141.

[14] Antonij Arhimandrit, Pastoral Theology, Tipografija Kievo-Pecherskoj Lavry, Kyiv, Russian Empire, 1854.

[15] Central State Historical Archive of Ukraine, Kyiv. Fund 711, inventory 3, file 584 - Reports of the Test Committees of the Academy on the Results of the Examinations, the Program of Academic Subjects, 1861.

[16] Central State Historical Archive of Ukraine, Kyiv. Fund 711, inventory 1, file 5963- Notes of the Subjects Taught in the Academy in 1867-1868 and 1868-1869 academic years, 1869.

[17] Central State Historical Archive of Ukraine, Kyiv. Fund 711, inventory 2, file 1000 - Service Records of the Teaching Staff of the Kiev Seminary and Religious Schools, Information on Students' Progress and Behavior, Notes of Lectures Given to Students during the 1824-1825 academic year.

[18] Central State Historical Archive of Ukraine, Kyiv. Fund 712, inventory 6, file 263 Syllabuses in Roman law, theology, Polish and French, Lists of Students of the Kiev Seminary and its Subordinate Schools and Information about their Academic Progress and Behavior for a September third of 1822.

[19] Institute of Manuscripts of the V. I. Vernadskyi National Library of Ukraine, Kyiv. Fund 160, file 370 - Synopses of Seminary Subjects (Schedule, Registers), 1817. 
[20] Central State Historical Archive of Ukraine, Kyiv. Fund 711, inventory 2, file 1007 - Service Records of the Teaching Staff of the Podole Seminary and Religious Schools, Information on Students' Progress and Behavior, Notes of Lectures Given to Students during the 1824-1825 academic year.

[21] Central State Historical Archive of Ukraine, Kyiv. Fund 711, inventory 2, file 1003 - Service Records of the Teaching Staff of the Yekaterinoslav Seminary and Religious Schools for the 1824-1825 academic year.

[22] Central State Historical Archive of Ukraine, Kyiv. Fund 711, inventory 1, file 1675 - Case of Making Synopsis for Teaching Subjects due to Transformation of Educational Part in Seminaries of Kiev Religious and Educational District, 10 of June - 19 of October 1840.

[23] Central State Historical Archive of Ukraine, Kyiv. Fund 711, inventory 2, file 3924 - The Notes of Lectures Given to Students of the Kharkiv, Kursk and Tiflis Seminaries for 18431845 academic years, 1845 .

[24] Central State Historical Archive of Ukraine, Kyiv. Fund 712, inventory 5, file 144 - Schedule and Registers of Examination Tests, Lesson Summaries, Reports on the Progress and Behavior, the List Information and Rating Lists of the Seminary Students for 1841-1842 and 1842-1843 academic years.

[25] N.Ju. Suhova, Pastoral Theology in the Russian Ecclesiastical School (XVIII - early XX century, Vestnik PSTGU I: Bogoslovie. Filosofija. 1 (2009) 25-43 [Online]. Available: https://cyberleninka.ru/article/v/pastyrskoe-bogoslovie-v-rossiyskoy-duhovnoy-shkole-xviiinachalo-XX-V

[26] Institute of Manuscripts of the V. I. Vernadskyi National Library of Ukraine, Kyiv. Fund 304, file 150 - Narkis, hieromonk (Sylvestrov) The Teachings of the Holy Fathers about Pastoral Service in General in the Church of Christ, 1853.

[27] Notes on the Project of the Transformation of Theological Seminaries (on the academic part), Orthodox Review. 15 (1864) 294-327.

[28] State and Needs of Ecclesiastical Educational Institutions, Orthodox Review. 8 (1861) 490495.

[29] O.K. Pronikov, Chernihiv Theological Seminary as a Culture Center of the Northern Left Bank of Ukraine, Chernihiv national pedagogical university bulletin. Pedagogical sciences. 131 (2015) 116-118 [Online]. Available: http://nbuv.gov.ua/UJRN/VchdpuP_2015_131_29

[30] Central State Historical Archive of Ukraine, Kyiv. Fund 711, inventory 2, file 5426 - Case of Inspection of Chernihiv, Podolsk and Poltava Religious Seminaries and Schools, the 22nd of January - the 11th of April 1858.

[31] Institute of Manuscripts of the V. I. Vernadskyi National Library of Ukraine, Kyiv. Fund 160, file 369 - Notes and Registers of Students with Marks before Testing, 1817.

[32] Central State Historical Archive of Ukraine, Kyiv. Fund 712, inventory 6, file 626 - Lesson Summaries, Progress and Behavior Reports, and Rating List of Students of the Kiev Seminary for the 1825-1826 Academic Year.

[33] Central State Historical Archive of Ukraine, Kyiv. Fund 712, inventory 5, file 257 - Schedule and Registers of Examination Tests, Lesson Summaries, Reports on the Progress and Behavior and the Rating List of the Seminary Students for 1843-1844 academic year.

[34] T. S. Tverdokhlib, Problem of the quality of pedagogical education in the Kiev Theological Academy (the first half of the XIX century), in All-Ukrainian Scientific and Practical Conference with International Participation-2017, Ternopil, Ukraine, 2017, pp. 269-270. [Online]. Available: http://dspace.tneu.edu.ua/handle/316497/21158 
[35] I.Lomachynska, Monasticity and Priesthood in the Orthodox Church, Human and the world. 2 (2002) $50-53$ [Online]. Available: https://risu.org.ua/ua/library/periodicals/lis/lis_2002/lis_02_02/34232/

[36] Encyclopedic Dictionary by Brockhaus and Efron, vol. XA (20), Semenovskaja Tipolitografija, Saint-Petersburg, Russian Empire, 1893 [Online]. Available: http://www.runivers.ru/bookreader/book10151/\#page/1/mode/1up

[37] Encyclopedic Dictionary by Brockhaus and Efron, vol. XIII (25), Semenovskaja Tipolitografija, Saint-Petersburg, Russian Empire, 1894 [Online]. Available: http://www.runivers.ru/bookreader/book10156/\#page/1/mode/1up

[38] Central State Historical Archive of Ukraine, Kyiv. Fund 711, inventory 2, file 1001 - Service Records of the Teaching Staff of the Volyn Seminary and Religious Schools for the 18241825 academic year.

[39] Central State Historical Archive of Ukraine, Kyiv. Fund 711, inventory 2, file 1003 - Service Records of the Teaching Staff of the Yekaterinoslav Seminary and Religious Schools for the 1824-1825 academic year.

[40] Central State Historical Archive of Ukraine, Kyiv. Fund 711, inventory 2, file 3990 - Service Records of the Teaching Staff of the Kherson, Podilla and Orel Seminaries and Religious Schools for the 1844-1845 academic year.

[41] Central State Historical Archive of Ukraine, Kyiv. Fund 711, inventory 2, file 3989 - Service Records of the Teaching Staff of the Voronezh, Poltava Seminaries and Religious Schools for the 1844-1845 academic year.

[42] Central State Historical Archive of Ukraine, Kyiv. Fund 711, inventory 2, file 1011 - Service Records of the Teaching Staff of the Chernigov Seminary and Religious Schools for the 18241825 academic year.

[43] Central State Historical Archive of Ukraine, Kyiv. Fund 711, inventory 2, file 1142 - Service Records of the Teaching Staff of the Kharkov Collegium and Religious Schools for the 18251826 academic year.

[44] Central State Historical Archive of Ukraine, Kyiv. Fund 711, inventory 2, file 3991 - Service Records of the Teaching Staff of the Minsk and Kiev Seminaries and Religious Schools for the 1844-1845 academic year.

[45] Theodosius Snegiryov, archim., Attempts to Determine the Subject, Methods and Aims of Pastorology as Theological Science in the Works of Domestic Theologians of the $19^{\text {th }}-20^{\text {th }}$ Centuries, Trudy Kyivskoi Dukhovnoi Akademii. 29 (2018) 317-321. 